\title{
Health Union and Bioethical Union: Does Hippocrates Require Socrates?
}

\author{
Niall COGHLAN* (10
}

\begin{abstract}
Health Union raises bioethical questions ranging from resource allocation and risk balancing to respect for specific bioethical prohibitions, as an analysis of the European Parliament's proposal for such a union shows. To date, European Union (EU) health law has succeeded in avoiding or circumscribing such questions, leading to the limited and inconsistent patchwork of EU bioethical provisions we currently have. Can this continue with a Health Union? This article argues that whilst full harmonisation is neither possible nor desirable, Health Union should entail a deepening of bioethical integration. This should occur via a robust legislative process involving citizen panels and ethical advisory group input; if Treaty change occurs, this process could be included in primary law. This is so for three reasons. First, addressing Health Union's unavoidable bioethical questions coherently and openly reduces the risk of inadequate protection and, conversely, of interest groups "smuggling in" unsupported answers. Second, this will ensure respect for primary law, including Article 2 TEU and Article 3 CFR. Third, EU biolaw offers a middle ground between limited national and weak international human rights law on bioethics, whilst also consolidating European identity.
\end{abstract}

\section{INTRODUCTION}

Coronavirus continues to burn through the human biosphere, exploiting and clogging the arteries of trade and movement on which contemporary civilisation depend. In response, after Economic and Monetary Union, Energy Union and Security Union, a project with an intrinsically human face is at last on the table: Health Union. That face's features which include possible Treaty change - are sketched out in the European Parliament resolution of 10 July 2020 (the EP Resolution). ${ }^{1}$

Yet Health Union's humanity brings with it sensitivities. Chief amongst these sensitivities are questions of bioethics, defined here as "the systematic study of human conduct in the area of the life sciences and health care, in so far as examined

\footnotetext{
* PhD researcher, European University Institute, Fiesole, Italy; Barrister, Lincoln's Inn, London, UK; email: niall.coghlan@eui.eu. I would like to thank Charlotte Piveteau, Francisco de Abreu Duarte, Gerry Coghlan, Joanne Scott and Panos Koutrakos for their helpful comments. The usual disclaimer applies.

1 European Parliament resolution of 10 July 2020 on the EU's public health strategy post-COVID-19 (2020/2691(RSP)). See also President von der Leyen's State of the Union address on 16 September $2020<$ https:// ec.europa.eu/commission/presscorner/detail/en/SPEECH_20_1655> (last accessed 16 September 2020).
} 
in the light of moral values and principles". ${ }^{2}$ Law incorporating bioethical norms is "biolaw". 3 Two questions thus arise. First, how far would Health Union raise bioethical questions? Second, how far would those questions be for the EU, rather than the Member States, to answer? In short: how far does the great doctor, Hippocrates, need the great moral philosopher, Socrates?

This article will first contend that the core Health Union proposals raise an array of bioethical questions (Section II). It will then argue that whilst Socrates appears to be banned from Brussels, closer inspection reveals that these bioethical questions must be confronted for reasons of balance, law and legitimacy (Section III). It will conclude with broader reflections on the role of ethics and values in the European Union (EU) (Section IV).

\section{The bioethical implications of Health Union}

Whilst there have been a number of calls for deeper health integration in response to COVID-19, ${ }^{4}$ the EP Resolution is substantially based on the Progressive Alliance of Socialists and Democrats' proposal (S\&D Proposal) of 12 May 2020.5 The S\&D Proposal provides a useful structure to break down the fifty-six-paragraph EP Resolution into its core elements. Table 1 does this. The "No." column contains arbitrary row numbering. The "EP Resolution" column sets out the key ${ }^{6} \mathrm{EP}$ proposals, structured (save the final two rows) around the S\&D Proposal. Paragraph references are to the EP Resolution. The "Bioethical implication(s)" column summarises some of the bioethical questions each set of proposals raises.

As Table 1 outlines, the majority of the EP Resolution's proposals raise bioethical questions of varying degrees of depth and controversy. This serves to illustrate a broader point. Health Union, by definition, entails making "standards, values, guidelines, and

\footnotetext{
2 W Reich (ed.), Encyclopedia of Bioethics (Cambridge, The Free Press 1978) p xix. This is thus wider than the application of moral values to emerging biotechnology (cf. D Beyleveld and R Brownsword, Human Dignity in Bioethics and Biolaw (Oxford, Oxford University Press 2001) p 44) and includes medical ethics (generally S Pattinson, Medical Law and Ethics $\left(5^{\text {th }}\right.$ edn, London, Sweet \& Maxwell 2017). Conversely, it is narrower than "global bioethics", which includes a broader reflection on humanity's relationship with its environment: H Ten Have, Global Bioethics: An Introduction (Abingdon, Routledge 2016) ch 3.

3 C Lavialle, "Introduction" in C Neirinck (ed.), De la bioéthique au bio-droit (Paris, Librairie générale de droit et de jurisprudence 1994).

4 European Parliament Resolution of 17 April 2020 on EU coordinated action to combat the COVID-19 pandemic and its consequences (2020/2616(RSP)) §§7-17; G Brauzzi, “European Union post Corona Crisis: Lessons learned” (New Europeans, 10 May 2020) <https://neweuropeans.net/article/3252/european-union-post-corona-crisis-lessonslearned > (last accessed 15 September 2020); N Nielsen, "EU Commission aspires for treaty change on health" (EU Observer, 29 May 2020) <https://euobserver.com/institutional/148503 > (last accessed 15 July 2020); and "Will Covid-19 lead to increased EU oversight of public health?" (EFNA) <https://www.efna.net/covid-19-will-eusee-more-powers-in-the-field-of-public-health/> (last accessed 15 July 2020).

5 S\&D, "A European Health Union: Increasing EU Competence in Health" (S\&D, 12 May 2020) <https://www. socialistsanddemocrats.eu/sites/default/files/2020-05/european_health_union_sd_position_30512_1.pdf>(last accessed 15 July 2020).

6 It in particular excludes proposals focused on labour law and various non-binding proposals that do not stem from the S\&D Proposal (eg $\S \S 48-53$ of the EP Resolution).
} 
Table 1. Key Health Union proposals and their bioethical implications.

\begin{tabular}{|c|c|c|}
\hline No. & EP Resolution proposal & Bioethical implication(s) \\
\hline 1 & $\begin{array}{l}\text { Stress testing and a minimum } \\
\text { healthcare standards directive. This } \\
\text { directive would seek to guarantee } \\
\text { patient safety, healthcare working } \\
\text { standards and "European resilience" } \\
\text { in the face of public health crises } \\
(\$ 10){ }^{7} \text { Healthcare funding and well- } \\
\text { being indicators would be included in } \\
\text { the European Semester ( } \$ 11) \text {. } \\
\text { Guaranteeing EU pharmaceutical } \\
\text { supply. Legislation to guarantee } \\
\text { pharmaceutical supply chains and } \\
\text { stimulate production within the EU, } \\
\text { and Commission guidelines on } \\
\text { pharmaceutical procurement } \\
\text { (\$\$22, 24). } \\
\text { European resilience. Commission-led } \\
\text { strategy to ensure "sound management }\end{array}$ & $\begin{array}{l}\text { Resource allocation, risk balancing } \\
\text { and evidential standards. How much } \\
\text { resource should be allocated to } \\
\text { healthcare? What criteria should be } \\
\text { used to determine whether a particular } \\
\text { treatment, medicine or medical device } \\
\text { is included in the minimum standards/ } \\
\text { protected supply, and who should } \\
\text { decide this? How should this system } \\
\text { be balanced as demographic pressure } \\
\text { on healthcare systems increases? } \\
\text { Ethics of specific treatments. Should } \\
\text { ethically sensitive treatments (eg } \\
\text { abortion, assisted reproduction (see } \\
\$ \$ 25-26 \text { ), specific experimental } \\
\text { treatments, euthanasia) be included } \\
\text { within the minimum standards? If so, } \\
\text { how? }\end{array}$ \\
\hline
\end{tabular}

\author{
European Health Response \\ Mechanism. This mechanism would \\ strengthen existing cross-border \\ emergency assistance mechanisms, \\ including by monitoring and ensuring \\ the proper functioning of strategic \\ reserves of medicines and medical \\ equipment $(\S \S 13-14) .{ }^{10}$
}

\begin{abstract}
Resource allocation, risk balancing and evidential standards. How much articular device protected supply, and who should decide this? How should this system be balanced as demographic pressure on healthcare systems increases?

Ethics of specific treatments. Should abortion, assisted reproduction (see $\S \S 25-26)$, specific experimental within the minimum standards? If so, how?
\end{abstract}

\begin{abstract}
Resource allocation. How much resource should be allocated to strategic reserves? What criteria should be used to determine whether a particular medicine or medical equipment is included in that strategic reserve, and who should decide this? How should shortages be addressed, and at whose cost?
\end{abstract}

7 The S\&D Proposal added that this should establish minimum healthcare standards, including minimum hospital beds, doctors and nurses per head of population, minimum health expenditure and "access and affordability of healthcare for all", including a "minimum permitted level of health coverage" (S\&D, supra, note 5, p 2).

8 The S\&D Proposal further referred to "protecting and secur[ing] citizens, managing critical infrastructures and taking full advantage of digitalization and automation" and assessing the "[n]eeds and resources available at local and regional level" (ibid, p 7).

9 Compare Council of the EU, "Council Conclusions on Common values and principles in European Union Health Systems" (2006/C 146/01) p 3. On the bioethics of health resource allocation, see Pattinson, supra, note 2 , ch 2 .

10 This latter function seems to originate in the S\&D Proposal for mandatory national inventories of medicines and medical devices (S\&D, supra, note 5, pp 4-5). 
Table 1. (Continued)

\begin{tabular}{|c|c|c|}
\hline No. & EP Resolution proposal & Bioethical implication(s) \\
\hline 3 & $\begin{array}{l}\text { Joint procurement and assessment and } \\
\text { transparency. Revision of relevant } \\
\text { law }{ }^{11} \text { to expand joint procurement } \\
\text { to routine use for "new innovative } \\
\text { antibiotics, new vaccines and new } \\
\text { curative medicines". This aims to } \\
\text { stimulate the creation of such } \\
\text { treatments, including particularly } \\
\text { for "treatments of rare diseases", to } \\
\text { avoid bidding wars between } \\
\text { Member States and to ensure } \\
\text { "equal and affordable access to } \\
\text { new treatments" ( } \S 17-18) \text {. } \\
\text { Adoption of the Health Technology } \\
\text { Assessment proposal, providing for } \\
\text { shared clinical assessment of new } \\
\text { medicines and devices ( } \$ 19 \text { ). }{ }^{12} \\
\text { Revival of the proposed Directive } \\
\text { on the transparency of net pricing } \\
\text { and reimbursement of particular } \\
\text { treatments }{ }^{13} \text { and the implementation } \\
\text { of the Clinical Trials Regulation } \\
\text { (\$§20-21). }{ }^{14}\end{array}$ & $\begin{array}{l}\text { Resource allocation, risk balancing } \\
\text { and evidential standards. What } \\
\text { criteria should be used to determine } \\
\text { whether a particular treatment should } \\
\text { be approved or prioritised for research } \\
\text { or procurement, and who should } \\
\text { decide this? How should prices be set } \\
\text { and the costs shared? Should suppliers } \\
\text { be subject to equitable benefit sharing } \\
\text { or similar obligations? } \\
\text { Ethics of specific treatments. What } \\
\text { ethical review and prohibitions, if } \\
\text { any, will apply to jointly procured } \\
\text { medicines and the research } \\
\text { underpinning them? Who should } \\
\text { determine this? }\end{array}$ \\
\hline
\end{tabular}

11 Decision 1082/2013/EU of the European Parliament and of the Council of 22 October 2013 on serious cross-border threats to health and repealing Decision No 2119/98/EC [2013] OJ L293/1, especially Art 5.

12 Commission, "Proposal for a Regulation of the European Parliament and of the Council on health technology assessment and amending Directive 2011/24/EU”, COM(2018) 51 final. The S\&D Proposal did not include this.

13 Commission, "Proposal for a Directive of the European Parliament and of the Council relating to the transparency of measures regulating the prices of medicinal products for human use and their inclusion in the scope of public health insurance systems" COM(2012) 84 final; “Amended Proposal ..." $\operatorname{COM(2013)~} 168$ final.

14 Regulation (EU) 536/2014 of the European Parliament and of the Council of 16 April 2014 on clinical trials on medicinal products for human use, and repealing Directive 2001/20/EC [2014] OJ L158/1 (not yet applicable).

15 K Fox, "The Illusion of Inclusion - The 'All of Us' Research Program and Indigenous Peoples' DNA" (2020) 383(5) New England Journal of Medicine 411.

16 See how the Health Technology Assessment proposal deals with these questions: Commission, supra, note 12, Recital 3 and Arts 2(f), 5(2), 6(5) and 12(2). 
Table 1. (Continued)

\begin{tabular}{|c|c|c|}
\hline No. & EP Resolution proposal & Bioethical implication(s) \\
\hline 4 & $\begin{array}{l}\text { Strengthening EU health agencies and } \\
\text { guidance. Substantial increases in the } \\
\text { competences of the ECDC and EMA } \\
\text { so that they can coordinate responses } \\
\text { to infectious diseases and crises. } \\
\text { Creation of an equivalent to the US } \\
\text { BARDA and continuation of } \\
\text { the European Medical Corps } \\
(\$ \$ 16,27-29) .^{17} \\
\text { Non-binding EU plans on antimicrobial } \\
\text { resistance would become mandatory } \\
\text { and an EU vaccination card would be } \\
\text { introduced ( } \$ 33-34) .{ }^{18} \\
\text { Standardisation of data collection and } \\
\text { sharing ( } \$ 36) \text { and actions to share } \\
\text { validated information and combat } \\
\text { disinformation (\$§35, } 37) .{ }^{19}\end{array}$ & $\begin{array}{l}\text { Resource allocation, risk balancing } \\
\text { and evidential standards. What } \\
\text { criteria should the ECDC, EMA and } \\
\text { EU BARDA use in identifying and } \\
\text { prioritising health threats? } \\
\text { Ethical aspects of these procedures. For } \\
\text { example, what balance should be set } \\
\text { between individual and collective } \\
\text { interests in restricting antibiotic access? } \\
\text { How should data sharing and medical } \\
\text { confidentiality be balanced? The } \\
\text { omitted S\&D Proposal (binding rules } \\
\text { on vaccination and hospitalisation and } \\
\text { the discharge of those with infectious } \\
\text { diseases) raises further questions } \\
\text { concerning informed consent, grounds } \\
\text { for refusal and autonomy. }\end{array}$ \\
\hline 5 & $\begin{array}{l}\text { One health. Action to reduce public } \\
\text { health threats arising from the } \\
\text { treatment of animals and the } \\
\text { environment ( } \$ 38) \text {. Expansion of the } \\
\text { European Reference Networks ( } \$ 40) \text {. }\end{array}$ & Limited bioethical implications. ${ }^{20}$ \\
\hline 6 & $\begin{array}{l}\text { Research and funding. Greater } \\
\text { coordination of EU and national } \\
\text { research funding of health. } \\
\text { Continuation of the EU4Health } \\
\text { Programme through long-term } \\
\text { investment, including "a dedicated EU } \\
\text { fund to strengthen hospital } \\
\text { infrastructures [sic] and health } \\
\text { services, subject to clear criteria" } \\
(\S \S 43,45-46)^{21}\end{array}$ & $\begin{array}{l}\text { Resource allocation, risk balancing } \\
\text { and evidential standards. What } \\
\text { criteria should be used to prioritise } \\
\text { particular treatments, hospitals or } \\
\text { health services, and who should } \\
\text { decide this? } \\
\text { Ethical bars. Will the ethical review } \\
\text { and prohibitions that apply to } \\
\text { EU-funded research apply to } \\
\text { coordinated national research and to } \\
\text { funding for health services, too? How } \\
\text { far should other national ethical } \\
\text { reviews and research bars be } \\
\text { harmonised? }\end{array}$ \\
\hline
\end{tabular}

\footnotetext{
17 These latter two proposals were not included in the S\&D Proposal.

18 Commission, “A European One Health Action Plan against Antimicrobial Resistance (AMR)" < https://ec.europa. eu/health/amr/sites/health/files/antimicrobial_resistance/docs/amr_2017_action-plan.pdf> (last accessed 15 July 2020). The S\&D Proposal envisaged other plans becoming mandatory: S\&D, supra, note 5, p 5.

19 The S\&D Proposal did not include the information and disinformation proposals.

20 But compare the broader field of "global bioethics": supra, note 2.

21 The S\&D Proposal contained stronger language on research coordination but weaker language on the Health Programme: S\&D, supra, note 5, pp 7-8.
} 
Table 1. (Continued)

\begin{tabular}{lll}
\hline No. & EP Resolution proposal & Bioethical implication(s) \\
\hline 7 & IP law. A robust IP system must be & Resource allocation. Does the existing \\
maintained and the WTO's & IP system incentivise and reward \\
Pharmaceutical Tariff Elimination & biomedical innovation and, if so, does \\
Agreement extended; however, the & it strike a fair balance with ensuring \\
Commission should explore "credible & affordability and access? Is \\
and effective alternatives to exclusive & consolidation and extension of this \\
protections", including de-linkage & Agreement fair?22 \\
$(\$ \S 23,44)$. & Ethical bars. Would the ordre public \\
& and ethical prohibition bars under \\
& Directive $98 / 44 /$ EC also apply to any \\
& alternative system? \\
& Resource allocation, risk balancing \\
& and evidential standards. What \\
& measures should be required in light \\
Care home standards. EU and national & of these three factors? Who should \\
legislation to address the high death & decide on these? \\
rate from COVID-19 within long-term & Specific ethical issues. How do the \\
residential facilities (\$31). & proposals reconcile relevant ethical \\
& principles (eg respecting residents' \\
& autonomy)?
\end{tabular}

BARDA = Biomedical Advanced Research and Development Authority; ECDC = European Centre for Disease Prevention and Control; EMA = European Medicines Agency; EP resolution = European Parliament resolution of 10 July 2020; EU = European Union; IP = intellectual property; S\&D Proposal = Progressive Alliance of Socialists and Democrats' proposal of 12 May 2020; WTO = World Trade Organization.

legislation ... more binding and the units ... more mutually dependent and tied to one another". ${ }^{23}$ Whatever the shape of the final legislation, Health Union is thus highly likely to raise bioethical questions. The question that follows is how those should be addressed.

\section{Health Union and Bioethical Union}

Policymakers' first reaction may be this: bioethical questions are often highly sensitive. Reaching consensus on such issues may prove painstakingly difficult. History seems to confirm this. For instance, as a result of its bioethical implications, the Biotechnology Directive was "one of the most heavily lobbied and controversial pieces of legislation ever produced through the European democratic process", took a decade of "difficult negotiation" and was followed by a legal challenge and eight sets of infringement

\footnotetext{
22 On intellectual property and bioethics, see generally JB Biddle, "Intellectual Property in the Biomedical Sciences" in JD Arras et al, The Routledge Companion to Bioethics (Abingdon, Routledge 2015).

23 H Vollaard and DS Martinsen, "The rise of a European healthcare union" (2016) 15 Comparative European Politics $337,338$.
} 
proceedings for non-transposition. ${ }^{24}$ It may be tempting, then, to try to avoid providing European answers to the above bioethical questions at all.

That temptation finds theoretical support in two common understandings of the EU. First, Floris de Witte's influential article "Sex, Drugs \& EU Law: The Recognition of Moral and Ethical Diversity in EU Law" 25 contended that moral and ethical laws are spontaneous exercises in self-expression by a particular community. Yet:

The EU itself cannot replicate the institutional and normative preconditions required for it to be a space of communal self-expression. It lacks the sophisticated political framework, its law lacks the capacity for socialization, its system of governance is too rigid to allow for the continuous re-negotiation of first principles, and (therefore) the affective ties between its population are too weak to allow for a meaningful exercise in self-expression of the parameters of permissive behaviour. ${ }^{26}$

In the absence of the "institutional preconditions that would allow for self-determination at the transnational level", attempts to Europeanise moral questions would lack legitimacy, "ro[b] citizens of the capacity to make moral sense of the communities in which they live" and be "partisan, hegemonic and authoritarian". ${ }^{27}$ Such questions should instead remain within the nation state (where such self-expression is possible), subject to the Court of Justice of the European Union's (CJEU) procedural proportionality review.

The second focuses on the constitutional orientation of the EU, and particularly its supposed "constitutional asymmetry". ${ }^{28}$ This image of the EU as fundamentally orientated towards economic and technical integration to the detriment of non-market values is common in the EU health law literature. ${ }^{29}$ Consistently with this, Favale and Plomer's seminal article on ethics in EU biotechnology law contended that:

As the Union is founded primarily on the economic goal of facilitating the expansion of a free market through the lifting of territorial and cross-border barriers to trade, there is no legal basis under the Treaties for concerted EU action aiming directly at harmonization and unification of national moral norms. ${ }^{30}$

\footnotetext{
24 Directive 98/44/EC of the European Parliament and of the Council of 6 July 1998 on the legal protection of biotechnological inventions [1998] OJ L213/13; G Porter, "The Drafting History of the European Biotechnology Directive" in A Plomer and P Torremans (eds), Embryonic Stem Cell Patents: European Law and Ethics (Oxford, Oxford University Press 2009) pp 3-4, 16-17.

25 (2013) 50 Common Market Law Review 1545. See also, supporting this argument, A Ott, "Differentiation through accession law: free movement rights in an enlarged European Union" in B de Witte et al (eds), Between Flexibility and Disintegration (Cheltenham, Edward Elgar 2017), p 196; and B van Leeuwen, "Euthanasia and the Ethics of Free Movement Law: The Principle of Recognition in the Internal Market" (2018) 19 German Law Journal 1417, 1420 23 (cf. 1432f).

26 de Witte, supra, note 25, 1550.

27 ibid, 1550, 1561.

28 Seminally, F Scharpf, "The asymmetry of European integration, or why the EU cannot be a 'social market economy"” (2010) 8(2) Socio-Economic Review 211.

29 T Hervey et al, Research Handbook on EU Health Law and Policy (Cheltenham, Edward Elgar 2017) p 9; see also pp 6-11, 20, 481, 493.

30 M Favale and A Plomer, "Fundamental Disjunctions in the EU Legal Order on Human Tissue, Cells \& Advanced Regenerative Therapies" (2009) 16(1) Maastricht Journal of European and Comparative Law 89, 94.
} 
They argued that whilst certain political and normative pressures have in fact led to the "infiltration" of moral norms into EU legislation, these were compromised by "the tension between the limits to the EU mandate, which is not supposed to harmonize ethical standards[,] and the growing pressure of fundamental principles", such as human rights. ${ }^{31}$

At first sight, the above three points - practical difficulty, institutional incompetence and constitutional orientation - plead against bioethical integration. Health Union should be technical and apolitical, with bioethical questions carved out and left to the Member States.

Closer inspection, however, reveals the flaws with this view. It is illusory and risks imbalances (Section III.1). Moreover, EU primary law and constitutional orientation favours bioethical integration (Section III.2), which would have salutary effects for efficacy, legitimacy and European identity (Section III.3).

\section{Health without bioethics: illusions and imbalances}

Hopes for Health Union without (some) Bioethical Union are illusory.

A first, obvious point is that limiting bioethical integration means limiting health integration. ${ }^{32}$ To date, EU health law has frequently "abstained" from answering bioethical questions, instead referring to national law or otherwise preserving national diversity. ${ }^{33}$ These abstentions limit integration. For instance, EU law extensively regulates the blood, tissue, cell and organ economies and, in principle, opposes persons selling their own body parts (the Voluntary Unpaid Donation (VUD) principle). However, only the Organ Directive includes this prohibition as a hardedged legal obligation, and EU law has not fully defined the line between selling and mere compensation (eg refreshments for donors). ${ }^{34}$ The resulting diversity has caused consequences that are "important, with some Member States putting up barriers to the

\footnotetext{
31 ibid, 103.

32 Compare S Weatherill, The Internal Market as a Legal Concept (Oxford, Oxford University Press 2017) p. 219, F Lafond, "Towards a European bioethics policy? Institutional structuring and political responses" in M Steffen (ed.), Health Governance in Europe: Issues, challenges and theories (Abingdon, Routledge 2005) p 169 and Commission, "Communication from the Commission to the European Parliament, the Council, the Economic and Social Committee and the Committee of the Regions: Life sciences and biotechnology - A Strategy for Europe" (2002/C 55/03) §4.2.

33 E Brosset, "Ce que dit le droit de l'Union dans le domaine de la bioéthique (et inversement)" (2019) Revue de l'Union européenne 30, §I(a).

34 Directive 2002/98/EC of the European Parliament and of the Council of 27 January 2003 setting standards of quality and safety for the collection, testing, processing, storage and distribution of human blood and blood components and amending Directive 2001/83/EC [2003] OJ L33/30, Art 20(1); Directive 2004/23/EC of the European Parliament and of the Council of 31 March 2004 on setting standards of quality and safety for the donation, procurement, testing, processing, preservation, storage and distribution of human tissues and cells [2004] OJ L102/48, Art 12(1); Directive 2010/45/EU of the European Parliament and of the Council of 7 July 2010 on standards of quality and safety of human organs intended for transplantation [2010] OJ L207/14, Art 13. See also Commission, "Report from the Commission to the European Parliament, the Council, the European Economic and Social Committee and the Committee of the Regions on the implementation of Directives 2004/23/EC, 2006/17/EC and 2006/86/EC setting standards of quality and safety for human tissues and cells" COM(2016) 223 final, pp 11-13 and "Report from the Commission to the European Parliament, the Council, the European Economic and Social Committee and the Committee of the Regions on the implementation of the Directives 2002/98/EC, 2004/33/EC, 2005/61/EC and 2005/62/EC setting standards of quality and safety for human blood and blood components" COM(2016) 224 final, p 9.
} 
movement of [blood, tissue and cells]". ${ }^{35}$ In the case of Health Union, it is, for instance, difficult to see how any meaningful provision could be included in the flagship minimum healthcare standards directive without significant agreement as to its bioethical questions (Table 1, row 1). ${ }^{36}$

Beyond this is a subtler but graver risk. Despite EU law's bioethical "abstentions", a significant body of EU biolaw has been built up since the 1990s. ${ }^{37}$ This has developed in a flawed way as a result of the tension analysed by Favale and Plomer. ${ }^{38}$ On the one hand, the language of fundamental rights and the "political reality of the forces seeking moral integration in Europe ... most notably the European Parliament" push for bioethical integration. ${ }^{39}$ On the other hand, on their account, the EU is constitutionally limited and Europe fundamentally divided. ${ }^{40}$ The EU's largely technical health law "has [thus] had to respond to political pressure to situate the legislation within an ethical frame", through incorporating "the largely open ended and indeterminate norms contained in ... EU human rights instruments which in turn guide [secondary law's] flexible and more specific ethical constraints". ${ }^{41}$ This process sometimes leads to weak or aspirational language; other times, the higher-level ethical norms "infiltrate" the law with binding norms; and still other times, there is a "middle ground" between the two. ${ }^{42}$ It in turn leads to three problems.

First, some EU bioethical provisions are weak or of limited relevance. A French Senate report on European ethical law thus derided the reduction of ethics "to an ornament ('placebo' ethics) or even instrument (ethics as 'alibi')". ${ }^{43}$ EU provisions on informed consent in clinical trials and in human substances law - caught between deferring to national and international law and setting EU requirements - have been criticised in this way. ${ }^{44}$

Second, conversely, other unsupported biolaw has "infiltrated" EU law. For instance, whilst many scholars (including Floris de Witte) criticise the CJEU for creating an autonomous definition of the "human embryo" in Brüstle, it is strongly arguable that the legislation in fact required this. ${ }^{45}$ Relatedly, EU biolaw frequently contains underspecified terms - starting with Article 3(2) of the Charter of Fundamental Rights' (CFR, "the Charter") prohibition of "eugenic practices", which has been

\footnotetext{
35 Commission, "Commission Staff Working Document: Evaluation of the Union legislation on blood, tissues and cells” SWD(2019) 375 final, p 50. See also pp 40-50, 66 and Case C-421/09 Humanplasma EU:C:2010:760.

36 The EP Resolution's omission of some of the flesh of the S\&D Proposal (supra, note 7) perhaps provides evidence of this.

37 S Hennette-Vauchez, "EU Law and Bioethics" in M Cremona et al (eds), New Technologies and EU law (Oxford, Oxford University Press 2017) p 41; Brosset, supra, note 33, §1(B).

38 Favale and Plomer, supra, note 30.

39 ibid, 111.

40 ibid, 103.

41 ibid, 111

42 ibid, 92-93, 107.

43 S Sutour and J-L Lorrain, Rapport d'Information fait au nom de la commission des affairs européennes sur la prise en compte des questions éthiques à l'échelon européen, Sénat No 67 2013-14, p 54 (my translation).

44 R Andorno, Principles of International Biolaw: Seeking Common Ground at the Intersection of Bioethics and Human Rights (Brussels, Bruylant 2013) ch 9; compare Favale and Plomer, supra, note 30, 107.

45 Case C-34/10 Brüstle v Greenpeace e.V., EU:C:2011:669, paras 25-26. Compare Case C-456/03 Commission v Italy EU:C:2005:388, paras 77-84.
} 
variously interpreted as limited to war crimes, as prohibiting gene editing or even as prohibiting two widespread practices (pre-natal diagnosis and pre-implantation screening for serious genetic defects). ${ }^{46}$ In the short term, these vague terms may contain conflict, but longer term, they embed legally binding norms that the CJEU must ultimately interpret. As Brüstle and other cases show, this risks Member States and Europeans being surprised by what EU biolaw requires. ${ }^{47}$

Third, Lafond's 2005 analysis still rings true: whilst there is a "Europeanization of politics concerning bioethics", the result is "nevertheless still fragmented and disparate". ${ }^{48}$ Specific provisions are agreed in individual pieces of sectoral legislation without adding up to a coherent bioethical policy. For instance, the variable approach to VUD noted above is incoherent and arguably inconsistent with the Charter. ${ }^{49}$

These problems are manageable whilst EU health law remains itself limited and fragmented. ${ }^{50}$ Indeed, the juge rapporteur for several leading bioethical cases has argued that the CJEU was able to extend biolaw rights precisely because it could limit the effects of its judgments to specific sectors of law. ${ }^{51}$ However, they become significantly more problematic in a genuine Health Union in which significant competence is transferred to the EU level. The first outcome risks that competence being accompanied by only illusory bioethical protection. For instance, including prohibitions on certain gene therapies or human reproductive cloning $^{52}$ in joint procurement or research law (Table 1, rows 2 and 6) may give the appearance of bioethical protection without in fact grappling with the core bioethical challenges these instruments raise. The second outcome risks particular interest groups ${ }^{53}$ or legislators 54 "infiltrating" EU law with unsupported bioethical norms. Finally, fragmentation and incoherence undermine the very concept of a maturing policy union.

The risk, then, is that Health Union arrives with the birth defect that has repeatedly afflicted EU policy: imbalance. Worker posting without sufficient worker

\footnotetext{
46 Respectively, S Heselhaus, "Human Dignity in the EU" in P Becchi and K Mathis (eds), Handbook on human dignity in Europe (Berlin, Springer 2019) p 958; C Dupré, The Age of Dignity (Oxford, Hart 2015) p 106 and European Group on Ethics in Science and New Technologies ("EGE"), "Statement on Gene Editing" <https://ec. europa.eu/research/ege/pdf/gene_editing_ege_statement.pdf> (last accessed 15 July 2020); and L Pellizza, "La future Constitution européenne et la bioéthique" <https://docplayer.fr/11875459-La-future-constitution-europeenneet-la-bioethique.html $>$ (last accessed 15 July 2020) p 6.

47 See, for instance, Humanplasma, supra, note 35, para 44. See also the Observations of Sweden and the UK in Brüstle, supra, note 45 (on file with author).

48 Lafond, supra, note 32, p 169.

$49 \operatorname{SWD}(2019) 375$ final, supra, note 35, p 66.

50 On the fragmentation of EU health law, see Hervey et al, supra, note 29, pp 6-7, 35, 241.

51 M Safjan, "La bioéthique dans la jurisprudence de la Cour" in A Roberto et al, Liber amicorum Antonio Tizzano (Turin, Giappichelli 2018). C-418/18 P Puppinck EU:C:2019:1113, paras 106-08 demonstrates this well.

52 Common in EU law: eg Regulation 1291/2013 of the European Parliament and of the Council of 11 December 2013 establishing Horizon 2020 - The Framework Programme for Research and Innovation (2014-2020) and repealing Decision No 1982/2006/EC [2013] OJ L347/104, Art 19(3); and Directive 98/44/EC, supra, note 13, Art 6(2).

53 COMECE, An Overview Report on Bioethics in the European Union (2009) < http://www.comece.eu/dl/ KlMkJKJOllkJqx4KJK/20091029PUBIO_EN.pdf> (last accessed 15 July 2020); HL Deb 24 February 2015, v759 cc1569-1627 (on mitochondrial donation's compatibility with Art 3 CFR); and the applicants in Puppinck, supra, note 51.
}

54 Compare Favale and Plomer, supra, note 30, 105, 108. 
protection, ${ }^{55}$ police and criminal measures without human rights and defence protection ${ }^{56}$ data retention without adequate protection: $:{ }^{57}$ now, the risk is health integration without adequate and agreed bioethical protection.

To avoid the reality and perception of falling into this trap, policymakers must not shy away from Health Union's bioethical implications. Rather, they should openly, consciously and coherently decide whether to Europeanise those implications and, if so, with what answer. But, returning to the tension highlighted by Favale and Plomer, is this in fact legally and constitutionally possible?

\section{Union primary law and constitutional orientation}

Matters have moved on since Favale and Plomer's 2009 article. EU primary law is no longer neutral as to bioethics. Article 3 CFR provides that everyone has the right to respect for their "physical and mental integrity". Within the fields of medicine and biology, this includes respect for informed consent and prohibitions on eugenics, human reproductive cloning and commercialisation of the human body and its parts (Article 3(2)). Article $21 \mathrm{CFR}$ requires non-discrimination in respect of age, disability, genetic features and property. The EU must "promote the application" of these rights. ${ }^{58}$ Health Union must thus both respect and promote these bioethical values. For instance, research and treatment funding must respect the Article 3 prohibitions, and decisions as to resource allocation must avoid discrimination. .9

Article 3 appears in the first Title of the Charter, entitled "Dignity". There are strong arguments that this Title fleshes out EU law's concept of human dignity, the first fundamental right (Article 1 CFR) and first Union value (Article 2 TEU). ${ }^{60}$ There is no space here to enter into long-standing debates as to the (in)determinacy of "human dignity". But we should notice that human dignity and bioethics are intimately linked, ${ }^{61}$ and that the CJEU has begun to shape the legal effect of both the Article 2 TEU values ${ }^{62}$ and of the right to human dignity. ${ }^{63}$ Health Union must respect and promote these: for instance, this

\footnotetext{
55 Directive (EU) 2018/957 of the European Parliament and of the Council of 28 June 2018 amending Directive 96/ 71/EC concerning the posting of workers in the framework of the provision of services [2018] OJ L173/16, Recital 4.

56 Eg V Mitsilegas, "The uneasy relationship between the UK and European criminal law: from opt-outs to Brexit?" (2016) 8 Criminal Law Review 519.

57 Case C-293/12 Digital Rights Ireland EU:C:2014:238.

58 Art 51(1) CFR. See B de Witte, "A competence to protect: The pursuit of non-market aims through internal market legislation" in P Syrpis (ed.), The Judiciary, the Legislature and the EU Internal market (Cambridge, Cambridge, University Press 2012) p 32.

59 Regarding acute rationing and discrimination, see K Liddell et al, "Who gets the ventilator? Important legal rights in a pandemic" (2020) 46 Journal of Medical Ethics 421, 424.

60 Dupré, supra, note 46, p 75; Heselhaus, supra, note 46, pp 951, 957f; Case C-377/98 Netherlands v Parliament and Council EU:C:2001:523, para 77.

61 Seminally, Beyleveld and Brownsword, supra, note 2.

62 Case C-619/18 Commission v Poland EU:C:2019:531. Compare Case C-331/16 K EU:C:2018:296, para 60. See A Jakab and D Kochenov, The Enforcement of EU Law and Values (Oxford, Oxford University Press 2016).

63 Case C-233/18 Haqbin v Federaal Agentschap voor de opvang van asielzoekers EU:C:2019:956, para 46; Joined Cases C-404/15 and C-659/15 PPU Aranyosi and Caldararu EU:C:2016:198, para 90; Joined Cases C-148/13 to C-150/ 13, A, B and C v Staatssecretaris van Veiligheid en Justite EU:C:2014:2406, para 65; Brüstle, supra, note 45, para 34; Netherlands $v$ Parliament, supra, note 60, paras 69-81.
} 
places limits on the basic treatments that can be excluded from the minimum healthcare directive (Table 1, row 1). Moreover, by fleshing out these rights' contours in secondary legislation, the democratic legislature can seek to influence their primary law content. ${ }^{64}$

These legal requirements do not, of course, require full bioethical integration. Article 5(3) TEU still requires subsidiarity. Here, as elsewhere, what is likely to emerge is a mixture of harmonisation and heterogeneity - the "internal market as a site of diversity", as Weatherill puts it. ${ }^{65}$ Openness and clarity as to which bioethical issues are and are not Europeanised will help reduce the infiltration referred to above. ${ }^{66}$ Floris de Witte's fear that ethical union entails "a monolithic creature: an autonomous, European-wide, concept of ordre public, which has (unsurprisingly) deeply majoritarian tendencies" is thus misconceived. ${ }^{67}$

This law, moreover, reflects a deeper constitutional point: "the all-market image of the EU legal order has probably always been a misconstrued caricature". ${ }^{68}$ The EU is not constitutionally constrained to ignore non-market values. ${ }^{69}$ As the Brexit process is making clear, mutual trust depends crucially on certain mutual standards. ${ }^{70}$ Indeed, primary law has long required a "high level of human health protection" in all policies (Article 152 TEC (Amsterdam); now Article 168 TFEU). EU law already embeds and spreads values in myriad areas: restricting genetically modified organisms (GMOs), requiring high data protection standards, imposing animal welfare requirements, providing high consumer protection and food standards, including as to ethical concerns, outlawing discrimination and setting minimum standards in criminal law. ${ }^{71}$ Neither Union law nor its constitutional orientation requires that bioethics be an area where the EU has a value void - quite the opposite.

64 P Syrpis, "The Relationship between Primary and Secondary Law in the EU" (2015) 52 Common Market Law Review 461, 462.

65 Weatherill, supra, note 32, especially ch 12.

66 Cf. A Héritier, "Covert Integration of Core State Powers: Renegotiating Incomplete Contracts" in P Genschel and M Jachtenfuchs, Beyond the Regulatory Polity?: The Integration of Core State Powers (Oxford, Oxford University Press 2013).

67 de Witte, supra, note 25, 1560. With respect, it is misconceived even with respect to the narrow example it cites, namely the Brüstle case (supra, note 45). Member States continue to enjoy "wide discretion" as to the ordre public provision of the Biotechnology Directive (Art 6(1)), despite the harmonisation of the Art 6(2) matters: para 29 of the judgment.

68 Hennette-Vauchez, supra, note 37, p 47.

69 de Witte, supra, note 58, especially p 36.

70 Eg the negotiating directives of 25 February 2020 (Council Note 5870/20 ADD 1 REV 3), §§94-113 and §118.

71 Inter alia Directive 2001/18/EC of the European Parliament and of the Council of 12 March 2001 on the deliberate release into the environment of genetically modified organisms and repealing Council Directive 90/220/EEC Commission Declaration [2001] OJ L106/1; Regulation (EU) 2016/679 of the European Parliament and of the Council of 27 April 2016 on the protection of natural persons with regard to the processing of personal data and on the free movement of such data, and repealing Directive 95/46/EC (General Data Protection Regulation) [2016] OJ L119/1; Council Regulation (EC) No 1099/2009 of 24 September 2009 on the protection of animals at the time of killing [2009] OJ L303/1; and Case C-363/18 Organisation juive européenne and another v Ministre de l'Économie et des Finances EU:C:2019:954; Council Directive 2000/78/EC of 27 November 2000 establishing a general framework for equal treatment in employment and occupation [2000] OJ L303/16; and Directive 2012/29/EU of the European Parliament and of the Council of 25 October 2012 establishing minimum standards on the rights, support and protection of victims of crime, and replacing Council Framework Decision 2001/220/JHA [2012] OJ L315/57. 


\section{Efficacy, legitimacy and European identity}

This leads to the final point. It is important not to fetishise national biolaw. Deep bioethical divisions exist in Europe - but, as Favale and Plomer concede, the same is true within Member States. ${ }^{72}$ "What legislation achieves on [bioethical] matters is at best compromise, not consensus". ${ }^{73}$ And "achieves" is the right word: as Brosset notes, biolaw does not merely formalise "an equilibrium between pre-existing values in each State, an equilibrium which incidentally is frequently impossible given how far values diverge. [The law] also participates itself in the 'constitution of these equilibriums' because it 'includes as well ... ethical concepts which inform our lives". ${ }^{74}$ This role of biolaw in creating as much as reflecting community values is important, and it points towards the role of biolaw in constituting communities and polities themselves. ${ }^{75}$

Moreover, purely national biolaw provisions frequently have limited effect. They are vulnerable to "democratically enshrined values [being] systematically annihilated by competition from more permissive judicial orders" - so-called "reproductive tourism" being one obvious example. ${ }^{76}$ In fact, modern bioethics' roots are deeply international (notably in the Nuremberg Doctors' trial and the Helsinki Declaration of 1964). ${ }^{77}$ To date, international human rights law has been the key language of international biolaw. ${ }^{78}$ This has had some successes, such as the remarkable rise of autonomy and its corollary, informed consent - in many legal orders. ${ }^{79}$ But this law is typically soft, underspecified or weakly enforceable. ${ }^{80}$ At the same time, it is made by intergovernmental conference or, in the case of the Helsinki Declaration, by a small group of professionals. These seem still further from Floris de Witte's idealised moral community than the EU's legislative process. ${ }^{81}$

\footnotetext{
72 Favale and Plomer, supra, note 30, p 95. Compare M Tallacchini's criticism of subsidiarity in EU bioethics as elevating an "ethics-of-the-States" that disempowers citizens: "Governing by Values. EU Ethics: Soft Tools, Hard effects" (2009) 47 Minerva 281, $294 \mathrm{f}$.

73 S Hennette-Vauchez, "Biomedicine and EU law: unlikely encounters?" (2011) 38(1) Legal Issues of Economic Integration 5, 10.

74 E Brosset, "Le droit international face à la bioéthique: vues depuis de droit européen" in G Le Floch and TF Graff, Santé et droit international (Paris, Pedone 2019) p 287 (my translation).

75 See also Hennette-Vauchez, supra, note 73, pp 25-27.

76 S Sana-Chaillé de Néré, "Gestation pour autrui et reconnaissance internationale des filiations" in D Szymczak et al (eds), Bioéthique et droit international et européen des droits de l'Homme (Paris, Pedone 2018) p 169 (my translation). Compare C Girard, "Le droit international de la bioéthique. L'universalisation à visage humain?" in S Hennette-Vauchez (ed.), Bioéthique, biodroit, biopolitique (Paris, Librairie générale de droit et de jurisprudence 2004) p 62.

77 See C Gauthier and D Szymczak, "Rapport Introductif” in Szymczak et al, supra, note 76, p 22: bioethics are "inherently an international object" (my translation).

78 Council of Europe, Convention for the Protection of Human Rights and Dignity of the Human Being with regard to the Application of Biology and Medicine ("Oviedo Convention") 1997 CETS 164, and its four protocols: UNESCO, Universal Declaration on the Human Genome and Human Rights 1997; Declaration on the Responsibilities of the Present Generations Towards Future Generations 1997; International Declaration on Human Genetic Data 2003; and Universal Declaration on Bioethics and Human Rights 2005.

79 T Vansweevelt and N Glover-Thomas, Informed Consent and Health: A Global Analysis (Cheltenham, Edward Elgar 2020) especially ch 12 .

80 J-P Marguénaud, "Conclusions Générales” in Szymczak et al, supra, note 76, p 268; R Ashcroft, "Could Human Rights Supersede Bioethics?” (2010) 10 Human Rights Law Review 639, 656-59; Girard, supra, note 76.

81 R Ashcroft, "The Troubled Relationship between Bioethics and Human Rights" in M Freeman, Law and Bioethics: Current Legal Issues Volume 11 (Oxford, Oxford University Press 2008) p 35.
} 
Here, as elsewhere, the EU potentially offers a middle ground. ${ }^{82}$ It could enshrine bioethical values that transcend the nation state and can better resist the ravages of globalisation. These international bioethical standards would potentially be at once more democratic and more binding than international human rights law. In addition to addressing Health Union's biolaw implications openly and robustly, legislators could take up the above French Senate report's suggestion to adopt a legislative procedure similar to French biolaw's, with citizen panels and ethical advisory groups feeding into the law. ${ }^{83}$ If Treaty change does occur, such a requirement could moreover be included in a new specific legal basis for biolaw provisions. Building on previous efforts to craft a distinctly European bioethics, ${ }^{84}$ this would contribute to constituting the EU's community and polity, and so to the EU's shift from a market-based towards a values-based identity. ${ }^{85}$

\section{Conclusion}

Where Health Union proposals raise bioethical questions, the Parliament and other actors will apply pressure in order to answer them. Ignoring or seeking to confine these is likely to perpetuate the current situation: a fragmented EU biolaw that frequently does less or more than it appears to. As with non-market values generally, ${ }^{86}$ legislators should embrace rather than deny these value-laden aspects of their work. They should follow an open and robust process to decide whether or not the bioethical question requires a European answer and, if so, what that should be. The European Group on Ethics in Science and New Technologies and the public should enjoy a genuine role in this, following (for instance) the French model for bioethical legislation. This would avoid the trap of imbalance, ensure compliance with Union primary law and build a stronger international biolaw that, in turn, strengthens the EU's legitimacy and identity.

The EU is now uniquely and powerfully placed to influence the future direction of Europe and of humanity in respect of some of the most important challenges the coming century will bring - from climate change through artificial intelligence to gene editing. Like the Health Union, each of those areas involves deep value and distributional clashes. ${ }^{87}$ Yet the EU continues to set these rules as if they were further

\footnotetext{
82 R Schütze (ed.), Globalisation and Governance: International Problems, European Solutions (Cambridge, Cambridge University Press 2018) pp 4-5.

83 Sutour and Lorrain, supra, note 31, p 53, referring to Code de la santé publique, art.L1412-1-1. Compare Interinstitutional Agreement between the European Parliament, the Council of the European Union and the European Commission on Better Law-Making [2016] OJ L123/1, §§2, 19, 25. Citizen panels would help address Tallacchini's concern, supra, note 72 .

84 Eg J Rentdorff and P Kemp, Basic Ethical Principles in European Bioethics and Biolaw, Report to the European Commission of the BIOMED-II Project (Copenhagen, Copenhagen Centre for Ethics and Law 2000); G Braibant, $L a$ Charte des droits fondamentaux: témoinage et commentaire (Paris, Points 2001) p 68; and N Lenoir, "Biotechnology, Bioethics and Law: Europe's 21st century challenge" (2006) 69(1) Modern Law Review 1.

85 M Bonelli, "From a Community of Law to a Union of Values: Hungary, Poland, And European Constitutionalism" (2017) 13 European Constitutional Law Review 793, 815f; M Frischhut, The Ethical Spirt of EU Law (Berlin, Springer 2019).

86 Compare de Witte, supra, note 58, p 44.

87 Compare, for instance, the analyses of the SIENNA project, available at $<$ https://www.sienna-project.eu $>$ (last accessed 16 September 2020).
} 
aspects of technical legislation, without open value clashes or enhanced democratic input. ${ }^{88}$ The Health Union provides a crucial opportunity for the EU to bring these value and ethical clashes out of the shadows. To put it another way: Hippocrates is not the only person who needs Socrates in this Union.

88 See, most recently, the Independent High-Level Expert Group on Artificial Intelligence's Ethics guidelines for Trustworthy AI (8 April 2019) <https://ec.europa.eu/digital-single-market/en/news/ethics-guidelines-trustworthy-ai> (last accessed 15 July 2020). 